\title{
CAREER PATTERNS AND JOB MOBILITY OF COLLEGE AND UNIVERSITY MUSIC FACULTY
}

Charles H. Aurand, Jr. Robert T. Blackburn

Job mobility is a complex phenomenon. This is true for the academic musician seeking a college position as well as for the music administrator searching for gifted faculty. Little has been elaborated about the input of academic musicians into the field of higher education; neither has there been evidence to substantiate reasons why musicians seek or change jobs. This study has a two-fold purpose: (l) to examine career patterns of music faculty in institutions accredited by the National Association of Schools of Music (NASM), and (2) to determine how these faculty perceive the importance of selected determinants of job choice as they relate to mobility.

The data from this study permit a description of the typical professor of music and also allow the testing of hypotheses generated from theory and related research. ${ }^{1}$ The specific hypotheses tested are described in a later section. According to a study by Gouldner, some variables may be considered as the "manifest social identities" of the faculty and as being "consensually regarded as relevant in a given setting." 2 These variables pertain to the faculty's professional

\footnotetext{
${ }^{1}$ David G. Brown, The Mobile Professors (Washington, D.C.: American Council on Education, 1967); A. Lawrence Fincher, Job Mobility of Academic Physicists in American Higher Education: A Preliminary Study (doctoral dissertation, The University of Michigan, 1969) ; Howard Marshall, The Mobility of College Faculty (New York: Pageant Press, Inc., 1964); Elwin F. Cammack, A Study of Factors Related to Mobility and Faculty Productivity and Achievement at Michigan State University: A Follow-Up Study (doctoral dissertation, Michigan State University, 1965) .

${ }^{2}$ Alvin W. Gouldner, "Cosmopolitans and Locals: Toward a Science of Latent Social Roles I," Administrative Science Quarterly, Vol. 2 (December 1957), p. 284.
} 
roles and qualifications such as institutional status, rank, tenure, and teaching specialty. Gouldner also points out "latent social identities," which are variables supposedly irrelevant to a given academic setting but likely to be strong attitudinal determinants-age, geographical region, ability, and musical productivity.

\section{Research Design}

The survey population was 50 percent of the music faculty employed at those member institutions of the NASM that are listed in the Directory of Music Faculties in American Colleges and Universities, 1968-1970.3 No effort was made to stratify the samples, as alternate names were selected from faculty lists. The faculty participating in the study were divided into eight geographical regions resembling the normal census groupings: the Northeast, East Northcentral, West Northcentral, Southeast, Rocky Montain, Pacific Coast, South, and Southwest. A questionnaire was mailed to 2,226 music faculty in January 1970; a second mailing was made in February. A total of 1,085 questionnaires were returned prior to May 1, 1970, which represents a 49 percent response. Adjusting for mismailings, inaccurate rosters, faculty who had moved, and late returns, the effective response rate is conservatively estimated to be 65 percent.

Eighty percent of the public tax-supported institutions and 63 percent of the private institutions participated in the study. Music faculty size of the institutions surveyed ranged from 3 to 108. Curriculums at these institutions ranged from one Bachelor of Arts curriculum to multiple listings of curriculums for baccalaureate, master's, and doctoral levels. All NASM full-member institutions listed in the College Music Society Directory, from two-year colleges to universities, were requested to respond to the survey instrument. The main sample questionnaire was four pages long and divided into seven sections: personal data, education, productivity, work experience, determinants of job choice, present position, and placement and comments.

\section{Results}

The primary data concerned the factors important to academic musicians either in selecting a new position or in remaining at the present job. The data are important to administrators in attracting new faculty to an institution or in retaining those faculty who have demonstrated their value to an institution. Job mobility offers advantages to the individual and the institution. For example, position changes provide opportunities

\footnotetext{
${ }^{3}$ National Association of Schools of Music, Directory 1969 (Washington, D.C.: National Association of Schools of Music, 1969); Harry B. Lincoln, ed., Directory of Music Faculties in American Colleges and Universities 1968-1970 (Binghamton, New York: The College Music Society, 1968).
} 
for movement to greater job responsibility, higher salary, movement upward in the academic prestige hierarchy, a change of administrators, or escape from a deteriorating academic environment. For the institution, new faculty members bring fresh ideas from graduate schools and other institutions. It is for these reasons that academic musicians in the NASM member institutions were requested to consider (l) which determinants of job choice were most important in the selection of a future position, (2) which determinants were important in the selection of their present position, and (3) how their present position satisfies their present needs with respect to these determinants.

The academic musicians indicated that the five most important variables in the selection of a new position are salary, courses to be taught, opportunity to participate in job decisions, research/performance facilities, and teaching load. The five least important factors were location near friends and relatives, climate, fringe benefits, congeniality of colleagues, and scheduling freedom (see Table 1).

Table 1

Future Position Determinants of Job Choice

\begin{tabular}{lcccc}
\hline \multicolumn{1}{c}{ Choice Variable } & Rank & Mean* & S. D. & N** \\
\hline Salary & 1 & 5.52 & 1.87 & 957 \\
Courses To Be Taught & 2 & 5.23 & 1.91 & 937 \\
Participation in Job Decisions & 3 & 4.82 & 1.58 & 916 \\
Research/Performance Facilities & 4 & 4.60 & 1.69 & 933 \\
Teaching Load & 5 & 4.53 & 1.76 & 938 \\
Quality of Students & 6 & 4.52 & 1.68 & 936 \\
Future Salary Prospects & 7 & 4.44 & 1.49 & 935 \\
Competency of Colleagues & 8 & 4.27 & 1.49 & 941 \\
Cultural Opportunities & 9 & 4.20 & 1.67 & 940 \\
Administration & 10 & 3.85 & 1.72 & 916 \\
Academic Rank & 11 & 3.70 & 1.51 & 929 \\
Prestige of Institution & 12 & 3.60 & 1.56 & 929 \\
Faculty Performance Opportunity & 13 & 3.58 & 2.07 & 930 \\
Scheduling Freedom & 14 & 3.55 & 1.63 & 927 \\
Congeniality of Colleagues & 15 & 3.55 & 1.50 & 929 \\
Fringe Benefits & 16 & 3.40 & 1.31 & 928 \\
Climate & 17 & 3.09 & 1.65 & 933 \\
Location near Friends/Relatives & 18 & 1.88 & 1.35 & 924 \\
\hline
\end{tabular}

* Based on a seven point scale, with seven (7) very satisfactory and one (1) very poor or unsatisfactory.

** The mean number of responses for this group of determinants is 932 .

When the musicians were requested to identify the past determinants of job choice important in the selection of their present position, the first five choices were salary, courses, research/performance facilities, prestige of the institution, and future salary. The determinants dealing with location near friends and relatives, climate, and fringe benefits occupied the last three positions, as shown in Table 2. 
Table 2

Past Position Determinants

\begin{tabular}{lcccc}
\hline \multicolumn{1}{c}{ Choice Variable } & Rank & Mean & S. D. & $\begin{array}{c}\text { Future } \\
\text { Position } \\
\text { Rank }\end{array}$ \\
\hline Salary & 1 & 4.57 & 2.39 & 1 \\
Courses I Would Teach & 2 & 4.24 & 2.24 & 2 \\
Research/Performance Facilities & 3 & 4.07 & 2.14 & 4 \\
Prestige of Institution & 4 & 4.02 & 2.11 & 12 \\
Future Salary Prospects & 5 & 3.97 & 1.83 & 7 \\
Competency of Colleagues & 6 & 3.81 & 1.84 & 8 \\
Quality of Students & 7 & 3.76 & 1.94 & 6 \\
Faculty Performance Opportunity & 8 & 3.68 & 2.25 & 13 \\
Cultural Opportunities & 9 & 3.62 & 2.12 & 9 \\
Participation in Job Decisions & 10 & 3.60 & 2.08 & 3 \\
Teaching Load & 11 & 3.40 & 2.00 & 5 \\
Administration & 12 & 3.29 & 1.96 & 10 \\
Congeniality of Colleagues & 13 & 3.22 & 1.79 & 15 \\
Scheduling Freedom & 14 & 3.09 & 1.91 & 14 \\
Academic Rank & 15 & 3.00 & 1.85 & 11 \\
Fringe Benefits & 16 & 2.65 & 1.60 & 16 \\
Climate & 17 & 2.65 & 1.93 & 17 \\
Location near Friends/Relatives & 18 & 2.27 & 1.96 & 18 \\
\hline
\end{tabular}

When faculty evaluated their present positions in terms of the eighteen job determinants, wide fluctuations occurred. Faculty who evaluated salary as the most important determinant in selecting a present or future position ranked this factor sixteenth in the evaluation of present position. Therefore, the data indicate that many of the faculty believe salaries are not satisfactory. Table 3 shows other major rank discrepancies from the present position determinants that differed from faculty expectations, including the factors of teaching load, future salary prospects, and research/performance facilities. These three determinants were all relatively highly ranked in Tables 1 and 2 as determinants of job choice.

The data show that the typical academic musician will either enter the field of higher education directly from graduate school or from K-12 school systems. His first move is downward in the prestige hierarchy. This typical musician will move slightly more than four times during a full teaching career, if he enters the field of higher education in his midforties. However, he will only move 2.5 times if he enters the profession in his early twenties. He possesses formal educational training equal to the master's degree plus one additional year of study. He will move most frequently during the early stages of his teaching career, when he holds the rank of instructor or assistant professor and does not possess tenure. If he is a music education teacher, it is highly probable he will average 1.25 more moves than if he taught composition, musicology, applied music, or history/literature.

The average academic musician is nearly forty-five years old, a male, and has two children. He will have received his formal academic training 
Table 3

Evaluation of Present Position

\begin{tabular}{lrrrrrr}
\hline \multicolumn{1}{c}{ Choice Variable } & & & & \multicolumn{3}{c}{$\begin{array}{c}\text { Previous } \\
\text { Rankings }\end{array}$} \\
& Rank & Mean & S. D. & $\begin{array}{r}\text { Fut/Past } \\
\text { Fut }\end{array}$ & N* $^{*}$ \\
\hline Teaching Courses Desired & 1 & 6.52 & 1.29 & 2 & 2 & 794 \\
Competency of Colleagues & 2 & 6.14 & 1.14 & 8 & 6 & 755 \\
Congeniality of Colleagues & 3 & 5.95 & 1.45 & 15 & 13 & 750 \\
Faculty Performance Opportunity & 4 & 5.91 & 1.58 & 13 & 8 & 764 \\
Participation in Job Decisions & 5 & 5.79 & 1.46 & 3 & 10 & 741 \\
Freedom To Leave Campus & 6 & 5.72 & 1.45 & 14 & 14 & 753 \\
Prestige of Institution & 7 & 5.68 & 1.41 & 12 & 4 & 772 \\
Administration & 8 & 5.53 & 1.48 & 10 & 12 & 750 \\
Cultural Opportunities & 9 & 5.40 & 1.95 & 9 & 9 & 770 \\
Quality of Students & 10 & 5.33 & 1.30 & 6 & 7 & 757 \\
Fringe Benefits & 11 & 5.23 & 1.83 & 16 & 16 & 745 \\
Climate/Recreation & 12 & 5.20 & 1.82 & 17 & 17 & 752 \\
Promotional Opportunities & 13 & 4.93 & 1.68 & 11 & 15 & 751 \\
Research/Performance Facilities & 14 & 4.84 & 1.88 & 4 & 3 & 760 \\
Future Salary Prospects & 15 & 4.65 & 1.34 & 7 & 5 & 756 \\
Present Salaries & 16 & 4.33 & 1.24 & 1 & 1 & 815 \\
Location near Friends/Relatives & 17 & 4.26 & 1.99 & 18 & 18 & 748 \\
Teaching Load & 18 & 3.79 & 1.48 & 5 & 11 & 760 \\
\hline
\end{tabular}

* The mean number of responses for this group of determinants is 760 .

in the Northeast or the East Northcentral regions of the United States. (Approximately one-half of the faculty with bachelor's and master's degrees and nearly two-thirds of the doctoral faculty received their degrees from these two regions.) The average academic musician has most likely performed as a soloist or a member of an ensemble during the past calendar year. The odds are one-in-three that he has written or will write a book or a composition during his career. He was attracted to his present position because of the first five determinants of job choicesalary, courses he would teach, a chance to participate in university governance, the teaching load, and the research/performance facilities. He ranks these same determinants less highly in an evaluation of his present position. He will, however, look for a future position using most of the same criteria he used in selecting his present position.

\section{Hypotheses}

One research hypothesis stated that "the determinants of job choice will be different for faculty in the various geographical regions." 4 When evaluated regionally by means of analysis of variance, the determinants

\footnotetext{
4 These regional differences may be examined in Charles H. Aurand, A Study of Career Patterns and Selected Determinants of Job Choice as They Affect Job Mobility of Music Faculty (doctoral dissertation, The University of Michigan, 1971), pp. $113-121$
} 
of job choice data indicated that regional rating differences do exist. Therefore, this hypothesis is supported because regional differences are statistically identifiable in all of the eighteen future position, thirteen of the past position, and fifteen of the evaluation of present position determinants of job choice. However, because in every instance the index of prediction association (IPA) was so low, there is little or no predictive value to the statistical conclusion.

Three hypotheses relate to the process of mobility and the independent variables of career pattern, direction of first move, age of entry into higher education, class of institution, highest degree, age, academic rank, major instrument, primary field of scholarship, teaching speciality, and tenure. One hypothesis was that "mobility of faculty will show a statistically significant relationship to age, academic rank, teaching specialty, tenure, and productivity." A significant relationship does exist between mobility and age of entry into higher education and between mobility and chronological age. Data from both of these age-related variables show that mobility generally decreases with age. The older one is and the older when entering higher education, the less likely one is to move. The mobility-academic rank relationship was statistically significant, with the greatest mobility occurring at the instructor level. It was found that mobility for tenured faculty was not significantly reduced and mobility for more productive faculty did not necessarily increase. Therefore, these portions of the hypothesis were rejected.

The relationship of mobility to teaching specialty (including major instrument and primary field of scholarship) failed to achieve statistically significant differences. Faculty in certain instrument areas, fields of scholarship, and teaching specialties do not differ significantly in amount of mobility from others. Another hypothesis stated that mobility for faculty performing in university or community ensembles will be less than for those not performing in ensembles. The chi-square and the $t$ test results between the means of these two groups were not found to be significant. Also tested was a hypothesis postulating that outstanding applied musical ability or publication productivity is to be associated with a stable or upward movement in the prestige hierarchy of higher education music schools. ${ }^{5}$ Musical ability and productivity were measured through production of books, compositions, articles, solos, and ensembles. These factors were compared with mobility, prestige of institutions, and upward or downward movement. In every instance the results failed to achieve the .05 level of significance.

\section{Conclusions}

The academic musician can gain a fuller understanding of the marketplace as it presently functions by studying the foregoing data. For

\footnotetext{
${ }^{5}$ The prestige hierarchy is a ranking of American colleges and universities based on quantitative data taken from the eighth (1960), ninth (1964), and tenth (1968) editions of the American Universities and Colleges published by the American Council on Education. See Aurand, "Career Patterns," pp. 137-138.
} 


\section{8/JRME}

example, the academic musician desirous of a new position should explore very carefully with his prospective employer the most important variables related to his potential satisfaction with the job and his economic well-being, to determine if the prospective job would be significantly better than his present position. He should probably spend as much time as possible during the job interview talking to the dean of the music school and other music faculty. By doing this, he can attempt to accurately appraise the long-range salary potential, present and projected teaching assignments, campus development plans for the fine arts, and the degree of opportunity he would have to determine the destiny of the academic program.

The music administrator, if he hopes to retain those he hires, should make a conscientious effort to present a factual, open account of his school to the job applicant. In the administrator's enthusiasm to employ, he should take into consideration the reasons the applicant gives for leaving his present position. If the dean wishes to attract and retain outstanding personnel, he should explore ways of keeping faculty loads within tolerable limits. He should strive to create an administrative climate that is sound in organizational theory and responsive to curricular change.

- Youngstown State University

Youngstown, Ohio

The University of Michigan

Ann Arbor, Michigan 